\title{
AUGUSTUS FREDERIC RUDOLF HOERNLE
}

Ir is with a sad heart that I claim the privilege of offering tribute to the memory of a great scholar and valued member of this Society. Those of us who have joined with him in the deliberations of our Council, or who have studied his many contributions to our Journal, need no reminder of the wide extent and depth of his learning; but for them, as well as for those whose interests have been in directions other than that in which he gained distinction, it is fitting to place on record an account of his life and of the services that he has rendered to Oriental science.

Augustus Frederic Rudolf Hoernle was born on October 19, 1841, at Secundra, near Agra, his father being the Rev. C. T. Hoernle, who, during the greater part of his life, served in India under the Church Missionary Society. He was sent to Europe in 1848, and received his early education in the kingdom of Wurtemberg. His university career began at Basle in 1858, and was continued from 1860 in London, where he studied Sanskrit under Goldstuicker. He returned to India in 1865, and was appointed Professor of Philosophy at Jay Narayan's College in Benares. While there he became a member of the Asiatic Society of Bengal, and in 1872 there appeared in its Journal from his pen the first of a series of "Essays in aid of a Comparative Grammar of the Gaurian Languages", which at once established his reputation as a philologist. These essays formed the ground work of the Comparative Grammar of the North Indian Vernaculars which he wrote while on leave in England during the years 1873-7, and which was published in 1878 after his return to India. It is unnecessary to dwell upon the excellent qualities of this work or on the admiration that it excited, gaining for it the Volney Prize of the Institut de France. Appearing simultaneously with the later volumes of Beames's 
Comparative Grammar (1872-9), it was in no sense a rival of the latter. Although both works dealt with the same subject, each author treated it in his own inimitable way. Each book completed and supplemented the other, and each presented the modern Indo-Aryan languages from a different point of view; so that both are still indispensable tools for every student in this field of inquiry.

On his return to India Hoernle became Principal of the Cathedral Mission College in Calcutta, which post he held till 1881, when he entered the Government Educational Service and was appointed Principal of the Calcutta Madrasah. In 1879 he was elected Honorary Philological Secretary of the Asiatic Society of Bengal, a position which included the editing of the philological side of the Society's Journal, and which he held for twelve years. These were the most fruitful of his Indian career. In the Journal and in the Proceedings there appeared numerous articles and shorter notes of which he was the author, mostly dealing with numismatics and epigraphy. Two important works also belong to this period: an edition of Caṇạ's Präkṛta-lakṣana (1880) and an edition and translation of the Uvãsaga-dasāo, the seventh Jaina Anga (1888-90). During the same period many articles by him also appeared in the pages of the Indian Antiquary, and, in conjunction with the present writer, there was begun the publication of a Bihāri Dictionary, which, however, press of other duties prevented our continuing after the first two instalments.

In the year 1881 fragments of an old birch-bark manuscript were dug up in the village of Bakhshäli on the North-West Frontier. It gave rise to considerable curiosity, but no one succeeded in reading it till it was sent to Hoernle by the Panjäb Government. He attacked it at once and with striking success. Although it had neither beginning nor end, and consisted merely of 
disorganized fragments with not a single leaf complete, he succeeded in deciphering the greater part of it and in showing that it was an ancient arithmetical treatise by an unknown author. Hoernle wrote several articles concerning it, perhaps the best known being the paper read before the Vienna Oriental Congress of 1886, which may be considered to be his finally expressed opinion on a difficult subject. The literary value of the manuscript was not very great, but its decipherment marked out Hoernle as one of the foremost authorities on archaic Indian scripts, and opened the way for much more important work of the kind in future years.

In 1884 the Aslatic Society of Bengal celebrated its centenary, and published a review of its work during the past hundred years. The valuable section of this dealing with Archæology, History, Literature, etc., was written by Hoernle, and to this he added two historical appendixes, both of which were subsequently reprinted, with additions, in the Indian Antiquary. In 1891 Hoernle resigned his post of Honorary Secretary, but continued till 1897 to be a member of the Council of the Society with which he had been so long connected, when it conferred upon him the highest honour which it was within its powers to grant by electing him as its President. Finally, in 1899, on the eve of his departure from India, it elected him an Honorary Member, or, as the name became in later years, an Honorary Fellow.

In the year 1890 Lieutenant (now Major-General) H. Bower, C.B., brought to India an ancient birch-bark manuscript which had been discovered by him at Kucha in Central Asia. At the time Hoernle was absent in Europe, but on his return in 1891 it was made over to him, and his first decipherment was published in the Proceedings of the Bengal Society for April of that year. It is through his work on this manuscript that Hoernle's name as an Orientalist is best known in Europe. 
Numerous essays written. by him culminated in the great edition published in parts between 1893 and 1912. This is not the place to give details regarding the results of Hoernle's investigations, and it is sufficient to state in his own words that " the discovery of the Bower manuscript and its publication in Calcutta started the whole modern movement of the archrological exploration of Eastern Turkistan". All scientific Europe set forth on the quest for further antiquities in this region, and more and more materials illustrating an ancient and now dead eivilization were gradually placed at the disposal of the learned world. The first to be discovered were more manuscripts. Such were those found by the Russians in 1892, or the Weber and Macartney manuscripts collected through British agency and brought to India. The latter were entrusted to Hoernle, and formed a portion of the subject-matter of his latest work. A direct result of the discoveries of these ancient writings was the triad of memorable expeditions to Central Asia carried out so successfully by Sir Aurel Stein, and other expeditions, such as those for the Russians by Klementz, for the Germans by Grïnwedel and von Le Coq, for the Japanese by Otani, and for the French by Pelliot.

The Bower manuscript deals largely with medical subjects, and this compelled Hoernle to study the hitherto almost untouched subjects of Hindū medicine and surgery. Here, again, we reap rich fruits from his investigations in a new branch of research. Besides minor essays he published in 1907 the first of his Studies in the Medicine of Ancient India, which deals with Osteology. Here the confused history of the writings of the earliest Indian physicians and surgeons was for the first time placed upon a scientifically sound basis.

The title of C.I.E. was conferred upon him by the Government of India in 1897, and in 1899 he retired from the Indian Educational Service. In the following 
year he joined this Society, and, besides contributing many important articles to our Journal, served us both on the Council and as Vice-President. On his return to England he settled with his family in Oxford, where he completed his work on the Bower manuscript and wrote his book on Osteology. A minor product of these days was a small history of India (1904), written in conjunction with Mr. Stark, and a model of lueid compression, embodying the latest scientific discoveries. Here, too, he undertook his last great work, the editing in collaboration with other scholars of the many manuscripts collected in Eastern Turkistan and brought home to England by himself and others. These included the Weber MSS., the Macartney MSS., and selections from the collection brought back by Sir Aurel Stein. The first volume was published in 1916, and only a few days before his death he wrote to me to say that he had just finished preparing for the press the manuscript. of the second.

The War has been a tragedy to all of us, but to few was it a deeper tragedy than to Hoernle. English alike by birth and by long associations, he still could not but feel more deeply than most the inevitable sorrows, and these past four years were in some respects the saddest of his life. His great wish was to live until the peace should come, and it is a consolation to his friends to know that in his last hours he heard the cheers in the street heralding the signing of the Armistice and passed away with the knowledge that his longing was fulfilled. He died, after a short illness, in the early hours of November 12, 1918.

In the pages of a scientific journal it is proper that attention should mainly be directed to his literary work; but an old and close friend cannot close these pages without a reference to his personal character. Hoernle had a genius for winning friends. He wrote much, and on much discussed matters, but not even those who were 
pronounced in their differences could impart heat or anger to the controversy. As for those who had the privilege of intimacy with him, his kindly personality, sometimes illuminated by a whimsical humour, endeared him to all. Ever courteous, ever modest, he was always ready to listen patiently to those who differed from him, and to point out, without a tinge of offence, where he thought that they were wrong. His profound knowledge of his own subjects, based as it was on almost incredible spadework, gave little chance to hasty theories in opposition to his own, and yet no one was more ready to accept a point that he had overlooked or to place his stores of learning at the disposal of others. Who that has known that happy home in the Madrasah and afterwards in Oxford will not bear me out in this? And the mention of that home, endeared to many old friends by memories that will not easily be effaced, recalls the kindly hostess with whom he shared it, and compels an expression of the profoundest sympathy in the grievous loss that she has sustained.

Hoernle was an Honorary Fellow of the Asiatic Society of Bengal, an Honorary Member of the American Oriental Society and of the Royal Society of Medicine, and a Foreign Associate Member of the Société Asiatique de Paris. As an appendix, I add a list of his writings so far as $I$ have been able to ascertain them.

G. A. Grierson.

\section{LIST OF THE WRITINGS OF DR. HOERNLE}

On Indian Philology

Sanskrit and Pãli

Remarks on the Palf Grammarian Kachchayana. Proc. ASB. 1882, p. 125.

Professor Râmehandra G. Bhânḍầrkar and the Giâthâ Dialect. Indian Antiquary, xii, p. 205, 1883.

On Elootibhate. Proc. A.S. B. 1887, p. 175. 


\section{Prakrit}

Subha Chandra, author of the Sabda Chintamani. Indian Antiquary, ii, p. 29, 1873.

A New Prakrit Grammar by Chanda. Proc. ASB. 1878, p. 178.

On a MS. of the Prakrit Grammar of Vararuchi. Id. 1879, p. 79.

On a MS. of an Unknown Prakrit Grammar. Id. 1880, p. 101.

The Prdkrita-Lakshanam, or Chanda's Grammar of the Ancient (Ársha).

Prákrit. Edited. Pt. i, Text with Critical Introduction and Indexes.

Bibliotheca Indica. Calcubta, 1880.

The Date of Trivikrams. Indian Antiquary, xii, p. 27, 1883.

See also Jainism.

\section{Modern Indo-Aryan Languages}

Essays in aid of a Comparative Grammar of the Gaurian Languages. JASB., pt. i, vol. xli, p. 120 , 1872 ; xlii, p. 59, 1873 ; xliii, p. $22,1874$.

On the term Gaurian as a Name for the Sanskritic Vernaculars of North India. Proc. ASB. 1872, p. 177.

On the Derivation of some peculiar Gaurian Verbs. Indian Antiquary, i, 1872 , p. 356 .

Genitive Postpositions : in reply to Dr. Pischel. Id. ii, p. 210, 1873.

Translation of the 27th Canto of the Prithirąja Râsau of Chând Bardâ. Id. iii, p. 17, 1874.

On some Prosodical Peculiarities of Chand. Id. iii, p. 104, 1874.

The Ka-Theory and Mr. Beames's Comparative Grammar. Id. v, p. $119,1876$.

A Comparative Grammar of the North Indian Vernuculars [or, in some copies, a C.G. of the Gaudian Languages], with Special Reference to Eastern Hindĩ. London, 1880.

A Collection of Hindi Roots, with Remarks on their Derivation and Classification. JASB. xlix, pt. i, p. 53, 1880.

Note on Bihárí Declension. Id. lii, pt. i, p. 159, 1883.

The Prithirāj Rāsau, an Old Hindī Epic, commonly ascribed to Clānd Bardāi. Edited and translated by Hoernle. Pt. ii, vol. i, Cantos 26-34. Bibliotheca Indica. Calcutta, 1886.

A Comparative Dictionary of the Bihüri Language. By A. F. Rudolf Hoernle and George A. Grierson. Calcutta. Pt. i, 1885 ; pt. ii, 1889.

\section{ON JAINISM}

The Uviragadasaio- being the Seventh Anga of the Jains. Bibliotheca Indica. Calcutta. Vol. i, Text and Commentary, 1890 ; vol. ii, Translation, 1888. ,

The Patfärali or List of Pontiffs of the Upakesa-Gachchha. Indian Antiquary, xix, p. 233, 1890.

Two Pat!ácalis of the Sarasvati-Gachcha of the Digambara Juins. Id. xx, p. 341, 1891.

Three further Patfätralis of the Digamharas. Id. xxi, p. 57, 1892.

See also Proc. ASB. 1898, pp. $39 \mathrm{fr}$ (a History of Jainism and Buddhism in Hoerule's I'residential Address). 


\section{Ox Nomigyatics and Rruatre SubJects}

\section{(Reports consiating of mere lists are not included.)}

On Gold Coins found in the Ahin Posh Tope near Jalalabad. Proc. ASB. 1879, pp. 122, 210.

On four Coins presented to the Bociety by Mr. Growse. Id., p. 173.

Monograms of the Baktro-Greek King Euthydemos Indian Antiquary, viii, p. 196, 1879.

On Roman, Indo-Scythian, and Gupta Coins sent by Mr. H. RivettCarnac. Proc. ASB. 1880, p. 118.

On Coins belonging to Mr. R. Nicholson. Id. 1881 , p. 39.

On Coins of the later Delhi Emperors. Id., p. 40.

On Coins, etc., from Khokhrakotè. Id., p. 71 .

A New Find of Early Muhammadan Coins. JASB. 1, pt. i, p. 53, 1881. On three Coins found near Mahanad. Proc. ASB. 1882, pp. 91, 104.

On Coins and Clay Figures from Toomluk. Id., p. 111.

On ten Silver Coins from Chhindwara. Id., p. 114.

On Coins from Midnapur. Id. 1883, p. 59.

On certain Gold Coins. Id., p. 143.

A Now Find of Muhammadan Coins of Bengal (Independent Period). JASB. lii, pt. i, p. 211, 1883.

On Gold Gupta Coins. Proc. ASB. 1884, p. 127 ; 1885, p. 2.

On Clay Seals from Sonait. Id. 1884, p. 137.

On Kashmiri Coins. Id. 1885, p. 4.

On an Ornament of Gold Roman Coins found in the Manikyála Tôp in the District of Rawal Pindi. Id. 1886, p. 86.

On Ancient Copper Coins found in Nepel. Id. I887, p. 144 ; 1888, p. 114.

On some new Bactrian and Gupta Coins. Id. 1888, p. 126.

On some new or rare Hindú and Muhammadan Coins. JASB., pt. i, No. i, lviii, p. 30,1889 ; No. ii, lix, p. 169 , 1880 ; No. iii, lxii, p. 23, 1893 ; No. iv, Ixvi, p. $133,1897$.

On an Inscribed Seal of Kumára Gupta. Id. lviii, p. 88, 1889. Cf. Proc. ASB. 1889, p. 194.

On Copper Coins of the Súri Dynasty. Id. lix, pt. i, p. 154, 1890.

On certain Indo-Sassanian Coins found in Márwárá. Id. lix, pt. i, p. 168, 1890.

On a forged Silver Ramtinki. Proc. ASB. 1890, p. 7.

On four-Copper Coins of Abdagases and Kadphises II. Id. 1895, p. 82.

Notes on Coins of Native States. JASB. lxvi, pt. i, p. 261, 1897.

Scytho-Bactrian Coins in the British Collection of Central Asian Antiquities. Indian Antiquary, xxvii, p. 225, 1898.

Indo-Chinese Coins in the same. Id. xxviii, p. 46, 1899.

Note on the British Collection of Central Asian Antiquities. Id. xxix, pp. 63, 98, 1900 .

\section{Epiaraphy, History, and Rruatud Subuhcts}

On a Pāli Inscription sent by Mr. A. M. Markham. Proc. ASB. 1880, p. 55.

Notes on a Rock-cut Inscription from Riwa. Indian Antiquary, ix, p. $120,1830$. 
On Relics from Buddha Gaya. Proc. ASB. 1881, p. 88.

Readings from the Bharhut Stûpa. Indian Antiquary, x, pp. 118, 255, 1881 ; xi, p. 25, 1882.

Readings from the Arian Pâli. The Sue Vihâra Inscription. Id. x, p. 324, 1881.

Revised Translations of two Kshatrapa Inscriptions. Id. xii, p. 27, 1883.

The Gaharwārs and Rāthors. Centenary Review of the Aviatic Society of Bengal, 1885, p. 199. Revised and reprinted in Indian Antiquary, xiv, p. 98, 1885.

The Pälas of Bengal. Centenary Review of the Asiatic Society of Bengal, 1885. Reprinted, with revision in Indian Antiquary, , xiv, p. 162, 1885.

Remarks on an Aśoka Insoription at Prabhása. Proc. ASB. 1887, p. 108.

A New Copper-plate Grant of Govinda-chandradeva of Kanauj. Indian Antiquary, xix, p. 249, 1890.

Note on Mr. W. Irvine's Article on Official Dates of Accession of Mughal Emperors. JASB. lxii, pt. i, p. 265, 1893.

Note on Mr. V. A. Smith's Paper on History and Coinage of the Gupta Period. Id. lxiii, pt. i, p. 210, 1894.

Note on thẹ Sohgaurã Copper-plate. Proc. ASB. 1894, p. 87.

The Guuhäți Copper-plate Grant of Indrapāla of Prāgjyotiọa in Āsām. JASB. lxvi, pt. i, p. 133, 1897.

The Nowgong Copper-plate Grant of Balavarman of Prāgjyotiģa in Āsäm. Id., p. 28.5.

Two Copper-plate Grants of Ratnapāla of Prägjyotį̧a in Āsäm. Id. lxvii, pt. i, p. 89, 1898.

An Epigraphical Note on Palm-leaf, Paper, and Birch-bark. Id. Ixix, pt. i, p. 83, 1800.

Some Problems of Ancient Indian History.

I. Coins of Vikramāditya and Harsha Vardhana. JRAS. 1903, p. 545 ; 1904, p. 357.

II. The Gurjara Empire. Id. 1904, p. 630.

III. The Gurjara Clans. Id. 1905, p. 1.

IV. Identity of Yaśodharman and Vikramäditya. Id. 1909, p. 89 ; Harshavardhana and Silāditya. Id., p. 446.

Who was the Inventor of Rug-paper? Id. 1903 , p. $663 ; 1904$, p. 548 ,

A History of India. By A. F. Rudolf Hoernle and Herbert A. Stark. Cuttack, 1904.

Kumāragupta the Patron of Vasubandhu. Indian Antiquary, xl, p. 181, 1911.

Kâlidâsa and Kâmandaki. Id. xli, p. 184, 1912.

\section{ON TIE BakhshïLĩ MaNuschipt}

On a Birch-bark MS. from Bakhsháll. Proc. ASB. 1882, p. 108. - Reprinted in Indian Antiquary, xii, p. 89, 1883.

The Bakhshâlı Manuscript. Indian Antiquary, xvii, pp. 33, 275, 1888.

On the Bakhshāī Manuscript. Proceedings of the Seventh International

Congress of Orientalists (Vienna, 1886), Aryan Section, p. 127. 
To these may be added :-

G. R. KAYz. Note on the Bakbshälf Manuscript. JASB., x.s., viii, p. 349, 1912.

\section{ON THE Bowhe MaNugCRIPT}

The Old Bipch MS. from Kashgaria. Proc. ASB. 1891, p. 54.

On the Date of the Bower MS. JABB., vol. lx, pt. i, p. 79, 1891.

An Instalment of the Bower Manuscript. Id., p. 135.

A Note on the Date of the Bower Manusoript. Indian Anliquary, vol. $x x i$, p. $29,1892$.

Another Instalment of the Bower MS. Id., p. 129.

The Third Instalment of the Bower MS. Id., p. 349.

The Bower Manuscript. Vol. xxii of the Now Imperial Series of the Archeological Survey of India. Calcutta, 1893-1912. A reprint of the Introduction, with additions, appeared as a Supplement to the Indian Antiquary, vol. xlii, 1913 ; xliii, 1914. Separate reprint, Bombay, 1914.

On othkr Manugoripts from Chatral Asia, and Connected Subjects The Weber MSS.-Another Collection of Ancient Manuscripts from Central Asia. JASB. lxij, pt. i, p. 1; 1893.

Fragments of an Ancient Manuscript from Central Asia. Proc. ASB. 1895, p. 84.

Three further Collectiops of Ancient Manuscripts from Central Asia. JASB. Ixvi, pt. i, p. 213, 1897.

A Note on some Block-prints from Khotan. Proc. ASB., p. 124, 1898.

Report on a British Collection of Antiquities from Central Asia. JASB. Ixviii, pt. i, p. 1, 1899 ; lxx, pt. i, p. 1, 1901.

Transliteration of Weber MSS., Part IX, and Mucartney MSS., Set I. Appendix to JASB., vol. lxx, pt. i, 1901.

On an Ancient Block-print from Khotan. JRAS. 1800, p. 321.

Vajracchedikā. Id. 1903, p. 364.

On Ancient MSS. from Khotan. Id. 1906, p. 695.

The Unknown Languages of Eastern Turkestan. Id. 1910, pp. 834, 1283 ; 1911 , p. 201 ; ii, p. $447,1911$.

Buddhist Monastic Terms samatittika, sapachina, tuttari-bhanga. Id. 1912 , p. 736 ; 1913 , p. 681.

A Peculiarity of the Khotanese Script. Id. 1915, p. 487.

An Early Text of the Saddharma-pundarika. Id. 1916, p. 269.

The Sutta Nipäta in a Sanskrit Version from Eastern Turkestan. Id. 1916, p. 709.

Sanskrit Version of the Suttu Nipäa. Id. 1917, p. 134.

Manuscript Remains of Buddhist Literature found in Eastern Turkestan.

Facsimiles with Transcripts Translations and Notes. Edited in conjunction with other scholars. Oxford, 1916. See also nnder Numismatics.

\section{Indian Medicine}

Studies in Ancient Indian Medicine.

I. The Commentaries on Suśruta. JRAS. 1906, pp. 283, 699.

II. On some Obscure Anatomical Terms. JRAS. 1906, p. 915 ; 1907, p. 1 . 
III. The Anthorship of the Caraka Sambitā. Archiv für Geschichto der Medizin, vol. i, p. 29, 1907.

IV. The Composition of the Caraka Samhita, and the Literary Methods of the Ancient Indian Medical Writers. JRAs. 1908 , p. 997.

V. The Composition of the Caraka Samhits in the Light of the Bawer Manuscript. JRAS. 1909, p. 857.

Itsing and Vägbhats. JRAS. 1907, p. 413.

Studies in the Medicine of Ancient India. Part I. Osteology or the

Bones of the Human Body. Oxford, 1907.

The Bheda Sambite in the Bower Manuscript. JRAS. 1910, p. 830.

The Vanaushadhidarpana or the Âyurvedic Materia Medica. Indian Antiquary, xli, p. 184, 1912.

\section{Miscellaninous}

"A Hindoo Reformer." (A report of Dayånanda Sarasvati's public disputation in Benares in 1869.) The Chriotian Intelligencer. Calcutta, March, 1870 , p. 79.

Report of Attendance at the Seventh International Congress of Orientalists, held at Vienna. Proc. ASB. 1887, p. 124.

Obituary Notice of Nawab Abdul Latif. Id. 1893, p. 138.

Obituary Notice of Major-General Sir A. Cunningham. Id. 1894, p. ${ }_{\text {v }}$ Obituary Notice of Mr. B. H. Hodgson. Id. 1894.

Presidential Address to the Asiatic Society of Bengal. Proc. ASB. 1898, p. 37. Principal Contents: Jainism and Buddhism, p. 39 ; Archeology and Epigraphy, p. 55 ; Central Asian Antiquities, p. 63 ; Ethnographic and Linguistic Surveys, p. 71 ; History of Old Calcutta, p. 81 .

\section{Professor JULiUs EgGeling, Pн.D.}

IN Julius Eggeling this Society has lost one who not only was an Honorary Member, but who began his connexion with it as Secretary just half a century ago.

$\mathrm{He}$ was born in the village of Hecklingen near the Hartz Mountains in the year 1842. Educated first at the Gymnasium (grammar school) of Bernburg, he then proceeded to study classical and Sanskrit philology at the Universities of Breslau and Berlin. He reached Breslau at the same time as another former Secretary of this Society, Professor Rhys Davids, both being bent on studying Sanskrit under Professor Stenzler. Being at the time the only pupils of that very sound scholar, they were naturally much thrown together. They thus became 